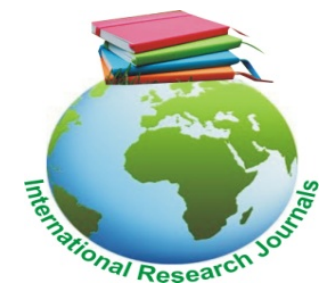

African Journal of Food Science and Technology (ISSN: 2141-5455) Vol. 6(7) pp. 194-203, November, 2015 DOI: http:/dx.doi.org/10.14303/ajfst.2015.063

Available online @http://www.interesjournals.org/AJFST

Copyright (C2015 International Research Journals

Full Length Research Paper

\title{
Evaluation of the effect of storage time and temperature on some physicochemical properties of juice and jam developed from two varieties of monkey kola (Cola parchycarpa, Cola lepidota)
}

\author{
${ }^{1 *}$ Helen O. Okudu ${ }^{2}$ Henrietta N. Ene-Obong \\ ${ }^{1}$ Department of Human Nutrition and Dietetics Michael Okpara University of Agriculture Umudike, Abia State \\ ${ }^{2}$ Department of Biochemistry (Nutrition and Dietetics Unit). Faculty of Basic Medical Science. University of Calabar, \\ Calabar. Cross River State, Nigeria. \\ Corresponding Author : E-mail: helenokudu@yahoo.com, Tel: +2340869189948.
}

ABSTRACT

\begin{abstract}
This study was aimed at evaluating the effect of storage time and temperature on some physicochemical properties of juice and jam developed from two varieties of monkey kola (Cola parchycarpa, Cola lepidota). Two varieties of monkey kola (white and yellow) were purchased from Umuahia Main Market Abia State Nigeria from five randomly selected vendors and pooled to obtain the samples for the jam and juice production. The $\mathrm{pH}$, total solid, soluble solid, titratable acidity, and total plate counts varied with storage time and temperature; the parameters studied were more stable in samples stored at refrigeration temperature $\left(12^{\circ} \mathrm{C}\right)$ than those stored at ambient temperature $\left(29-32^{\circ} \mathrm{C}\right)$. There was no significant change in specific gravity throughout storage period. Under ambient storage at week 4 C.parchycarpa jam had the least total plate count $(42.5 \mathrm{Cfu} / \mathrm{g})$. Under refrigeration $\left(12^{\circ} \mathrm{C}\right) \mathrm{Cola}$ lepidota jam had the least (22.5Cfu/g) plate. C.parchycarpa juice was more stable than Cola lepidota juice at both ambient and refrigeration temperatures. From the result of this study, it can be concluded that the shelf-life of the products (jam and juice) can be extended by storing them in the refrigerator. Further investigation on how to keep the products longer is however recommended.
\end{abstract}

Keywords: monkey kola, stability, physicochemical, microbial load, juice, jams

\section{INTRODUCTION}

Fruits are an important component of a healthy diet; however, they are highly perishable and as a result large quantities are lost post harvest. Improper handling, packaging, storage and poor post harvest management cause producers and traders in Pakistan 20-30\% loss of this important commodity (Tahir et al., 2002). In Nigeria, $40 \%$ of food losses occur at post-harvest and processing levels of the food chain (CTA, 2012). Processing plays important role in the conservation and better utilization of fruits and vegetables; it also ensures fair returns to growers to improve their economic condition which in turn help to mitigate the problem of under-employment during off-seasons in the agricultural sectors (Vidhya and Narain, 2010). Monkey kola is a fruit of the family of sterculiaceae and belongs to a group called drupes (Pamplona-Roger, 2008). It is made up of three varieties: red (Cola latertia), yellow (Cola parchycarpa) and white (Cola lepidota) (Singh et al., .2010). The pod of the yellow variety is roundish, while the white variety has more cylindrical shape. Monkey kola is identified by 


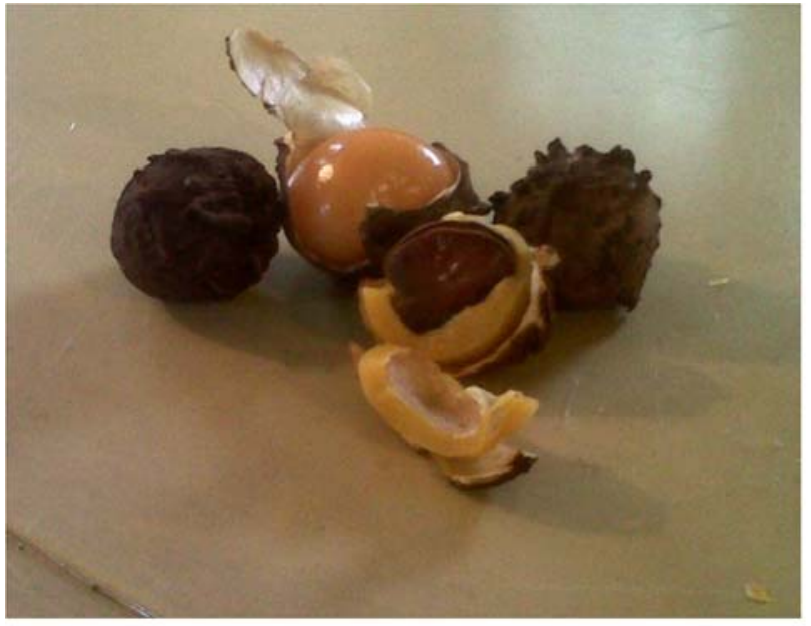

Monkey Kola (Yellow variety)

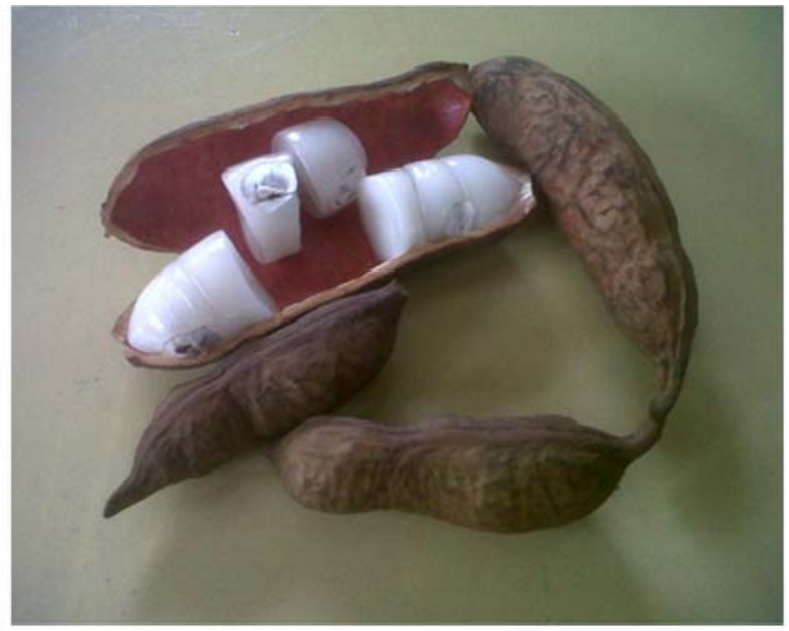

Monkey Kola (White variety)

Figure 1. Pictorial image of the Cola parchycarpa (yellow) and Cola lepidota (white) varieties.

various local names in Southern Nigeria ("achicha" or "ohiricha" in Igbo and "ndiyah" in Efik). It is used as famine food in some parts of Africa. Monkey kola is rich in micronutrients (Ene-Obong et al., 2014) and also has some health benefits (Singh et al., 2010). The seed of monkey kola is not edible, but the waxy pulp is relished by people due to its sugary taste. The fruit is cultivated throughout the tropical regions of the world; it is commonly found in Southern Nigeria between the months of June to November (Ogbu et al., 2007). In Nigeria monkey kola is mostly consumed fresh and like most fruits and vegetables it has a very short life span probably due to its high moisture content. To conserve it throughout the year monkey kola can be processed into products like juice and jam (Umeh and Nwadialu, 2010; Okudu and Ene-Obong, 2015). Quality parameters of fruit products, such as color, acidity, soluble solids, texture, $\mathrm{pH}$, total acidity among others are usually affected by processing and storage (Wicklund et al., 2005; Kviliene et al., 2006). Storage temperature is the prime limiting factor for shelf life of most of products developed from fruits. Studies have been done on the development, pasteurization, nutrition, antioxidant content and activities of monkey kola jam and juice (Ene-Obong, 2015; Okudu et al., 2015); however, there is no report on the effect of storage time and temperature on the physicochemical and microbiological properties of jam and juice produced from monkey kola. This work is therefore designed to investigate the storage stability of monkey kola jam and juice at ambient $\left(29-32^{\circ} \mathrm{C}\right)$ and refrigeration temperature $\left(12^{\circ} \mathrm{C}\right)$ for a period of four weeks.

\section{MATERIALS AND METHODS}

\section{Source of materials/ selection of fruits}

Two varieties of monkey kola (white and yellow) were purchased from Umuahia Main Market Abia State Nigeria from five randomly selected vendors and pooled to obtain the samples for the jam and juice production. Mature and undamaged fruits were selected for the production of jam. Sorting was done by hand and any fruit that was moldy was removed. Grading of fruits was done based on firmness, size, maturity, colour, shape and freedom from foreign matters, insect damage or mechanical injury. The fruits were washed using potable water. The fruits were open longitudinally with a sharp kitchen knife to remove the seeds. The pulp was placed in water containing lemon juice $(250 \mathrm{ml}$ lemon juice per liter of water) to stop them from browning.

\section{Preparation of jam}

A modified method as described by Adepoju et al. (2010) was used to prepare the jam. Grating was done manually using kitchen grater. Kenwood kitchen blender 


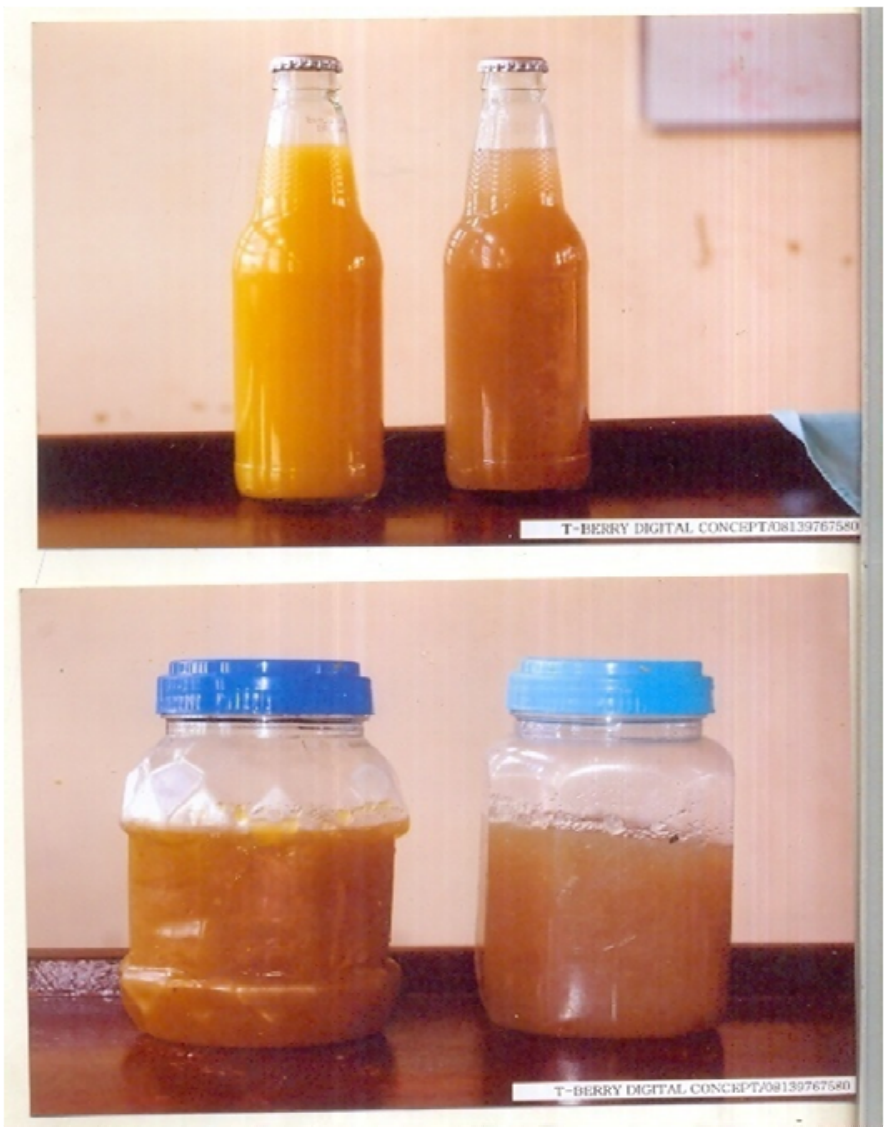

Figure 2. Pictorial image of the Cola parchycarpa (yellow) and Cola lepidota (white) products (juice and jam).

(Model KMC 500) was used to blend and homogenize the pulp. To $500 \mathrm{~g}$ of the pulp were added $500 \mathrm{~g}$ of sugar and $250 \mathrm{ml}$ of water. Twenty (20) $\mathrm{ml}$ of lemon juice and a pinch of salt were also added to enhance gel formation, improve colour and flavor of the jam. The mixture was left at room temperature for 45 minutes and then cooked slowly with occasional stirring for twenty (20) minutes. The cooked jam was poured into a sterilized bottle and allowed to cool at room temperature $\left(29-32^{\circ} \mathrm{C}\right)$.

\section{Preparation of juice}

Juice preparation as described by 'the wonder of carrot juice (The wander of carrot juice. 2013) was adopted for the preparation of juice. Six hundred (600) g of monkey kola (pulp) was cut into sizes of about $1 / 2 \mathrm{~cm}$ and placed in an electric blender; one cupful of the pulp was placed in blender at a time until the blender was $3 / 4$ ways filled. Twenty milliliter of water was added to the monkey kola in the blender for each blend. A total of $100 \mathrm{ml}$ of water was used for blending. The monkey kola was blended into a smooth pulp. The pulp was removed and poured into a large mixing bowl. Two hundred and fifty (250) $\mathrm{ml}$ of water was added to the pulp. A clean muslin cloth was used to filter the pulp. The monkey kola juice was drained into another container through a clean muslin cloth so as to stop any unblended pulp from getting into the final product. Twenty five grams of sugar was added. The juices were pasteurized at $70^{\circ} \mathrm{C}$ for 20 minutes.

\section{Shelf-life study}

Aqueous solution from the jam was prepared as described by Vidhya and Narain (2010), by weighing about $25 \mathrm{~g}$ of the sample and dissolving it in $200 \mathrm{ml}$ of potable water. The aqueous solution was kept in a boiling water bath for 1 hour. The sample was allowed to cool and diluted to $250 \mathrm{ml}$ with distilled water. The sample was filtered using a muslin cloth. Physicochemical test was carried out on the filtrate. The products (jam and juice) 
Table 1. The effect of storage temperature and time on the $\mathrm{pH}$ of monkey kola products (juice and jam)

\begin{tabular}{|c|c|c|c|c|c|c|c|c|}
\hline Storage Time & $\begin{array}{l}\text { CPJm } \\
29-32^{\circ} \mathrm{C}\end{array}$ & $\begin{array}{r}\mathrm{CPJm} \\
12^{\circ} \mathrm{C}\end{array}$ & $\begin{array}{l}\text { CLJm } \\
29-32^{\circ} \mathrm{C}\end{array}$ & $\begin{array}{l}\text { CLJm } \\
12^{\circ} \mathrm{C}\end{array}$ & $\begin{array}{l}\text { CPJu } \\
29-32^{\circ} \mathrm{C}\end{array}$ & $\begin{array}{l}\text { CPJu } \\
12^{\circ} \mathrm{C}\end{array}$ & $\begin{array}{l}\text { CLJu } \\
29-32^{\circ} \mathrm{C}\end{array}$ & $\begin{array}{r}\text { CLJu } \\
12^{\circ} \mathrm{C}\end{array}$ \\
\hline Week 0 & $4.5 \pm 0.1^{a}$ & $4.5 \pm 0.1^{a}$ & $4.5 \pm 0.1^{a}$ & $4.5 \pm 0.7^{a}$ & $4.2 \pm 0.7^{\mathrm{a}}$ & $4.2 \pm 0.7^{\mathrm{a}}$ & $3.9 \pm 0.7^{a}$ & $3.9 \pm 0.7^{a}$ \\
\hline Week 1 & $3.8 \pm 0.1^{b}$ & $4.5 \pm 0.1^{\mathrm{a}}$ & $3.8 \pm 0.1^{\mathrm{b}}$ & $4.4 \pm 0.7^{\mathrm{a}}$ & $4.2 \pm 0.1^{\mathrm{a}}$ & $4.2 \pm 0.1^{\mathrm{a}}$ & $3.9 \pm 0.7^{\mathrm{a}}$ & $3.9 \pm 0.1^{\mathrm{a}}$ \\
\hline Week 2 & $3.4 \pm 0.1^{c}$ & $4.4 \pm 0.1^{a}$ & $2.9 \pm 0.0^{c}$ & $4.4 \pm 0.7^{a}$ & $3.9 \pm 0.1^{\mathrm{ab}}$ & $4.2 \pm 0.1^{a}$ & $2.9 \pm 0.2^{b}$ & $3.9 \pm 0.7^{a}$ \\
\hline Week 3 & $3.0 \pm 0.4^{d}$ & $4.2 \pm 0.2^{a}$ & $2.7 \pm 0.3^{c}$ & $4.1 \pm 0.1^{b}$ & $3.2 \pm 0.4^{d}$ & $3.7 \pm 0.7^{b}$ & $2.8 \pm 0.3^{b}$ & $3.8 \pm 0.1^{b}$ \\
\hline Week 4 & $2.3 \pm 0.1^{\mathrm{e}}$ & $3.2 \pm 0.1^{\mathrm{b}}$ & $2.3 \pm 0.2^{c d}$ & $3.8 \pm 0.7^{c}$ & $3.0 \pm 0.1^{b}$ & $3.2 \pm 0.2^{c}$ & $2.4 \pm 0.4^{c}$ & $3.6 \pm 0.1^{c}$ \\
\hline
\end{tabular}

Means with different superscripts along the same row are statistically different from each other $(P<0.05)$. CPJu C.parchycarpa juice; CLJu - C.lepidota juice; CPUJm - C.parchycarpa jam;CLUJm - C.lepidota jam; Room Temperature $29-32=\mathrm{C} ;$ Refrigeration temperature $-12^{=} \mathrm{C}$.

were pasteurized at $60^{\circ} \mathrm{C}$ for 15 minutes produc15minutes in a water bath. Each of the products was divided into two equal parts using sterile containers. One part was stored in the refrigerator in sterile tight covered sample bottles while the second portions were stored at room temperature $\left(30 \pm 2^{\circ} \mathrm{C}\right)$. Storage was done for a period of four (4) weeks in order to determine the effect of storage time and temperature on the qualities $(\mathrm{pH}$, specific gravity, soluble solids, and total solid, titratable acidity and microbial load) of the products.

\section{pH Determination}

The $\mathrm{pH}$ was measured using $\mathrm{pH}$ meter (Jenway, 3310). Ten (10) milliters of each of the sample was measured into $100 \mathrm{ml}$ beaker. The electrode of the $\mathrm{pH}$ meter was placed inside the sample and the $\mathrm{pH}$ was read directly from the screen of the meter when the pointer became steady.

\section{Determination of Soluble Solid, Total Solid, Specific gravity and Titratable acidity}

The method of oven drying as described by AOAC (2006) was used to determine the soluble solids of the products. The total solid was determined by oven method (AOAC 2006). The pyconometer method (AOAC, 2006) was used to test for specific gravity. The acidity of the sample was determined using AOAC (2006) method.

\section{Determination of microbial load}

The microbial load (bacteria and mould) from products (juice and jam) was determined by the total plate count method described by the International Commission of Microbiological Specification of Food (ICMSF, 1978). One milliliter of each of the product was measured separately into two test tubes containing $9 \mathrm{ml}$ of distilled water to make it up to $10 \mathrm{ml}$. From $1 \times 10^{-1}$ dilution, $1 \mathrm{ml}$ from each test tube was measured out and diluted to $10 \mathrm{ml}$ in separate test tubes to form another fold of dilution $10^{-2}$. Ten (10) fold serial dilutions of the samples were made. Eight (8) grams of agar powder was weighed out and dispersed in $250 \mathrm{ml}$ distilled water in a conical flask. The mixture was sterilized by autoclaving at $126^{\circ} \mathrm{C}$ for 15 minutes. The prepared medium was stored at room temperature. Each plate was inoculated with $0.5 \mathrm{ml}$ of the products sample from each serial dilution. The inoculum was carefully spread evenly over the entire plate and incubated at $37^{\circ} \mathrm{C}$ for 48hours. (Uniscope SM 9023). After 24-hour incubation period, the number of colonies were counted using colony counter and the colonies were multiplied by the dilution factor. The results were recorded as colony forming units per $\mathrm{ml}\left(\mathrm{Cf} \mu \mathrm{ml}^{-1}\right)$.

\section{Statistical Analysis}

All determinations were done in duplicates. The data generated were entered into the computer and analyzed using Statistical Package for Social Sciences (SPSS version 16.0) Means and standard deviation were calculated for values obtained from the analysis. Analysis of variance (ANOVA) was used to compare the values obtained. Level of significance was accepted at $p<0.05$.

\section{RESULTS AND DISCUSSION}

The effect of storage temperature and time on the $\mathrm{pH}$ of monkey kola products (juice and jam).

Table 1 shows the effect of storage temperature and time on the $\mathrm{pH}$ of jam and juice prepared from monkey kola. The $\mathrm{pH}$ of $C$.parchycarpa jam stored at room temperature $\left(29-32^{\circ} \mathrm{C}\right.$ ) were stable for few days (less than a week) 
Table 2. The effect of storage temperature and time on the specific gravity of Monkey kola products (juice and jam).

\begin{tabular}{|c|c|c|c|c|c|c|c|c|}
\hline Storage T & $\begin{array}{l}\text { CPJm } \\
29-32^{\circ} \mathrm{C}\end{array}$ & $\begin{array}{r}\mathrm{CPJm} \\
12^{\circ} \mathrm{C}\end{array}$ & $\begin{array}{l}\text { CLJm } \\
29-32^{\circ} \mathrm{C}\end{array}$ & $\begin{array}{l}\text { CLJm } \\
12^{\circ} \mathrm{C}\end{array}$ & $\begin{array}{l}\text { CPJu } \\
29-32^{\circ} \mathrm{C}\end{array}$ & $\begin{array}{l}\mathrm{CPJu} \\
12^{\circ} \mathrm{C}\end{array}$ & $\begin{array}{l}\text { CLJu } \\
29-32^{\circ} \mathrm{C}\end{array}$ & $\begin{array}{r}\text { CLJu } \\
12^{\circ} \mathrm{C}\end{array}$ \\
\hline Wk 0 & $1.02 \pm 0.0$ & $0.02 \pm 0.0$ & $1.01 \pm 0.1$ & $1.0 \pm 0.07$ & $1.02 \pm 0.0$ & $1.02 \pm 0.0$ & $1.01 \pm 0.1$ & $1.01 \pm 0.1$ \\
\hline Wk 1 & $02 \pm 0.1$ & $2 \pm 0.0$ & $1.02 \pm 0.1$ & 1.02 & 0.1 & $1.02 \pm 0.0$ & $1.02 \pm 0.1$ & $1.02 \pm 0.1$ \\
\hline k 2 & $03 \pm 0.0$ & $1.02 \pm 0.1$ & $1.03 \pm 0.0$ & $1.02 \pm 0.0$ & $=0.0$ & $1.02 \pm 0.1$ & $1.03 \pm 0.0$ & $1.02 \pm 0.0$ \\
\hline Wk 3 & $1.03 \pm 0.1$ & $1.02 \pm 0.1$ & $1.03 \pm 0.1$ & $1.02 \pm 0.1$ & $3 \pm 0.1$ & $1.02 \pm 0.1$ & $1.03 \pm 0.1$ & $1.02 \pm 0.1$ \\
\hline Wk 4 & $1.04 \pm 0.1$ & $1.03 \pm 0.0$ & $1.04 \pm 0.1$ & $1.03 \pm 0.1$ & $1.04 \pm 0.1$ & $1.03 \pm 0.0$ & $1.04 \pm 0.1$ & $1.03 \pm 0.0$ \\
\hline
\end{tabular}

Means with different superscripts along the same row are statistically different from each other $(\mathrm{P}<0.05)$.CPJu - C.parchycarpa juice; CLJu - C.lepidota juice; CPUJm - C.parchycarpa jam;CLUJm - C.lepidota jam; Room Temperature -29 - $32=0$; Refrigeration temperature $-12=0$.

while there was no significant decrease $(p>0.05)$ in $\mathrm{pH}$ of the sample stored at refrigeration temperature $\left(12^{\circ} \mathrm{C}\right)$ until the $4^{\text {th }}$ week of storage when the $\mathrm{pH}$ decreased to 3.2. This indicates that storage of C.parchycarpa under refrigeration temperature reduced $\mathrm{pH}$ changes suggesting better product stability. The $\mathrm{pH}$ changes in jam from C.lepidota followed a similar trend when stored at ambient temperature $\left(29-32^{\circ} \mathrm{C}\right) . \mathrm{pH}$ of C.lepidota jam stored at refrigeration temperature $\left(12^{\circ} \mathrm{C}\right)$ was more stable than that of C.parchycarpa jam stored at the same temperature. $\quad \mathrm{pH}$ of C.parchycarpa juice stored at ambient temperature $\left(29-32^{\circ} \mathrm{C}\right)$ was stable for one week while the one stored in refrigeration temperature $\left(12^{\circ} \mathrm{C}\right)$ was stable for two weeks. Juice from C.parchycarpa stored at ambient temperature showed a significant decrease in $\mathrm{pH}(\mathrm{p}<0.05)$ after 2 weeks storage period. The $\mathrm{pH}$ values decreased from 4.2 to 3.0. For juice samples stored at refrigeration significant decreases in $\mathrm{pH}$ were observed by the $3^{\text {rd }}$ and $4^{\text {th }}$ weeks of storage. $C$. lepidota juice stored at $29-32^{\circ} \mathrm{C}$ showed significant $\mathrm{pH}$ reduction after the $2^{\text {nd }}$ week of storage $\mathrm{pH}$ values ranged from $\mathrm{pH} 4.2$ for fresh samples to $\mathrm{pH} 2.4$ after 4 weeks of storage. There were no significant changes in the $\mathrm{pH}$ of juices stored at refrigeration temperature until after 3 weeks of storage. The drop in $\mathrm{pH}$ signifies deterioration in quality of the product. The $\mathrm{pH}$ was higher at week 0 will hinder the proliferation of pathogenic and spoilage microorganisms in juice. The drop in $\mathrm{pH}$ in the samples was more pronounced at room temperature than storage under refrigeration. The results generally show that the higher the $\mathrm{pH}$, the lower the acidity of the juice. This indicated that more acids were produced at higher temperature $\left(28^{\circ} \mathrm{C}\right)$ than at lower temperature $\left(12^{\circ} \mathrm{C}\right)$ during storage. This observation may also be due to a greater rate of carbohydrate utilization in the sample stored at room temperature by microorganism leading to increased acidity (Fasajiro et al., 2005; Ashaye et al., 2006). Decrease in pH was also reported by Safdar et al. (2012) on jam prepared from different mango varieties.
However, the finding in this study was not in line with the report of Vidhya and Nadhya (2010) where they found no decrease in $\mathrm{pH}$ of Limonia acidissima fruit jam stored for 90 days. Decrease in $\mathrm{pH}$ of food product is said to be proportional to increase in acidity (Hussain et al., 2008; Safdar et al., 2012). The hydrogen ions generated from the acids produced by microorganisms are responsible for the decrease in $\mathrm{pH}$ values. The difference in $\mathrm{pH}$ values was observed to be consistent with titratable acidity. Saka et al. (2007) reported a similar finding in a work they carried out on some indigenous fruits.

\section{The effect of storage temperature and time on the specific gravity (SP) of monkey kola products (juice and jam).}

Table 2 shows the effects of storage temperature and time on specific gravity of jam and juices from two varieties of monkey kola stored at different temperatures. There were no significant differences $(p>0.05)$ in specific gravity of the jam and juice samples stored for the period of 4 weeks. The results indicated minimum and insignificant changes in the overall weight of the products within the storage period. Significant changes in soluble solids are an indication that probably microorganisms are using up nutrients in the juice for their growth or multiplication; that does not however translate into significant changes in weight of the juice. At week 0 the specific gravity of the juices (1.0- 1.02) was similar to $1.02-1.03$ reported for cow's milk (Ihekoronye and Ngoddy, 1985). A beverage with such specific gravity would be smooth when drinking (Ihekoronye and Ngoddy, 1985).

The effect of storage temperature and time on the total solids (TS) of monkey kola products (jam and juice) (\%).

The effect of storage temperature and time on the total 
Okudu and Ene-Obong 199

Table 3. The effect of storage temperature and time on the total solids (TS) of monkey kola products (jam and juice) (\%).

\begin{tabular}{|c|c|c|c|c|c|c|c|c|}
\hline Storage Time & $\begin{array}{l}\text { CPJm } \\
29-32^{\circ} \mathrm{C}\end{array}$ & $\begin{array}{r}\mathrm{CPJm} \\
12^{\circ} \mathrm{C}\end{array}$ & $\begin{array}{l}\mathrm{CLJm} \\
29-32^{\circ} \mathrm{C}\end{array}$ & $\begin{array}{l}\text { CLJm } \\
12^{\circ} \mathrm{C}\end{array}$ & $\begin{array}{l}\mathrm{CPJu} \\
29-32^{\circ} \mathrm{C}\end{array}$ & $\begin{array}{l}\mathrm{CPJu} \\
12^{\circ} \mathrm{C}\end{array}$ & $\begin{array}{l}\text { CLJu } \\
29-32^{\circ} \mathrm{C}\end{array}$ & $\begin{array}{l}\text { CLJu } \\
12^{\circ} \mathrm{C}\end{array}$ \\
\hline Wk 0 & $10.2 \pm 0.1^{a}$ & $10.2 \pm 0.1^{\mathrm{a}}$ & $11.9 \pm 0.1^{\mathrm{a}}$ & $11.9 \pm 0.1^{a}$ & $9.7 \pm 0.7^{\mathrm{a}}$ & $9.7 \pm 0.7^{\mathrm{a}}$ & $9.4 \pm 0.1^{a}$ & $9.4 \pm 0.1^{\mathrm{a}}$ \\
\hline Wk 1 & $9.2 \pm 0.2^{b}$ & $10.6 \pm 0.2^{a}$ & $10.6 \pm 0.1^{\mathrm{a}}$ & $11.8 \pm 0.1^{\mathrm{a}}$ & $9.7 \pm 0.7^{\mathrm{a}}$ & $9.7 \pm 0.7^{\mathrm{a}}$ & $9.4 \pm 0.1^{a}$ & $9.4 \pm 0.7^{\mathrm{a}}$ \\
\hline Wk 2 & $7.2 \pm 0.2^{c}$ & $10.1 \pm 0.1^{a}$ & $8.8 \pm 0.1^{b}$ & $11.5 \pm 0.1^{a}$ & $8.6 \pm 0.2^{b}$ & $9.7 \pm 0.7^{\mathrm{a}}$ & $8.8 \pm 0.1^{b}$ & $9.4 \pm 0.7^{\mathrm{a}}$ \\
\hline Wk 3 & $5.4 \pm 0.1^{d}$ & $9.6 \pm 0.2^{\mathrm{ab}}$ & $8.4 \pm 0.2^{b}$ & $10.6 \pm 0.2^{b}$ & $6.6 \pm 0.2^{c}$ & $9.6 \pm 0.1^{a}$ & $6.9 \pm 0.1^{c}$ & $9.3 \pm 0.1^{\mathrm{a}}$ \\
\hline Wk 4 & $4.7 \pm 0.1^{d}$ & $8.6 \pm 0.1^{b}$ & $8.6 \pm 0.2^{\mathrm{C}}$ & $6.9 \pm 0.1^{c}$ & $4.1 \pm 0.0^{d}$ & $9.5 \pm 0.3^{a}$ & $6.7 \pm 0.2^{c}$ & $9.3 \pm 0.1^{a}$ \\
\hline
\end{tabular}

Means with different superscripts along the same row are statistically different from each other $(\mathrm{P}<0.05)$. CPJu - C.parchycarpa juice; CLJu - C.lepidota juice; CPUJm - C.parchycarpa jam;CLUJm - C.lepidota jam; Room Temperature -29 - 32=C; Refrigeration temperature $-12^{\circ} \mathrm{C}$.

Table 4. The effect of storage temperature and time on the soluble solids (SS) of monkey kola products (jam and juice) (\%).

\begin{tabular}{|c|c|c|c|c|c|c|c|c|}
\hline Storage Time & $\begin{array}{c}\text { CPJm } \\
29-32^{\circ} \mathrm{C}\end{array}$ & $\begin{array}{r}\mathrm{CPJm} \\
12^{\circ} \mathrm{C}\end{array}$ & $\begin{array}{l}\text { CLJm } \\
29-32^{\circ} \mathrm{C}\end{array}$ & $\begin{array}{l}\text { CLJm } \\
12^{\circ} \mathrm{C}\end{array}$ & $\begin{array}{l}\text { CPJu } \\
29-32^{\circ} \mathrm{C}\end{array}$ & $\begin{array}{l}\text { CPJu } \\
12^{\circ} \mathrm{C}\end{array}$ & $\begin{array}{l}\text { CLJu } \\
29-32^{\circ} \mathrm{C}\end{array}$ & $\begin{array}{l}\text { CLJu } \\
12^{\circ} \mathrm{C}\end{array}$ \\
\hline Wk 0 & $7.5 \pm 0.1^{\mathrm{a}}$ & $7.5 \pm 0.2^{a}$ & $7.9 \pm 0.1^{a}$ & $7.9 \pm 0.1^{\mathrm{a}}$ & $6.1 \pm 0.2^{\mathrm{a}}$ & $6.1 \pm 0.2^{a}$ & $6.5 \pm 0.7^{a}$ & $6.5 \pm 0.7^{a}$ \\
\hline Wk 1 & $6.3 \pm 0.1^{b}$ & $7.4 \pm 0.1^{\mathrm{a}}$ & $5.5 \pm 0.1^{b}$ & $7.7 \pm 0.1^{\mathrm{a}}$ & $6.1 \pm 0.1^{a}$ & $6.1 \pm 0.1^{a}$ & $6.5 \pm 0.7^{a}$ & $6.5 \pm 0.7^{a}$ \\
\hline Wk 2 & $5.6 \pm 0.2^{\mathrm{bc}}$ & $7.3 \pm 0.1^{\mathrm{a}}$ & $4.7 \pm 0.1^{b}$ & $7.3 \pm 0.1^{\mathrm{a}}$ & $5.8 \pm 0.2^{\mathrm{a}}$ & $6.1 \pm 0.7^{\mathrm{a}}$ & $5.1 \pm 0.8^{b}$ & $6.5 \pm 0.7^{\mathrm{a}}$ \\
\hline Wk 3 & $4.6 \pm 0.1^{c}$ & $7.1 \pm 0.1^{\mathrm{a}}$ & $4.3 \pm 0.1^{b}$ & $7.2 \pm 0.1^{\mathrm{a}}$ & $4.9 \pm 0.2^{b}$ & $6.1 \pm 0.4^{\mathrm{a}}$ & $4.1 \pm 0.1^{c}$ & $6.5 \pm 0.7^{\mathrm{a}}$ \\
\hline Wk 4 & $3.6 \pm 0.1^{d}$ & $6.7 \pm 0.1^{\mathrm{ab}}$ & $3.8 \pm 0.1^{b c}$ & $6.6 \pm 0.2^{b}$ & $3.4 \pm 0.2^{c}$ & $5.5 \pm 0.2^{b}$ & $3.3 \pm 0.2^{d}$ & $5.3 \pm 0.2^{b}$ \\
\hline
\end{tabular}

Means with different superscripts along the same row are statistically different from each other $(\mathrm{P}<0.05)$. CPJu - C.parchycarpa juice; CLJu - C.lepidota juice; CPUJm - C.parchycarpa jam;CLUJm - C.lepidota jam; Room Temperature -29 - $32=6$; Refrigeration temperature $-12=0$.

solids of monkey kola products stored for 4 weeks is shown on Table 3 . The result shows that the C.parchyarpa jam stored under refrigeration $\left(12^{\circ} \mathrm{C}\right)$ was stable for two weeks while the sample stored at ambient temperature had steady total soluble solid for less than a week. Total solids decreased as storage period increase in jam from C.parchyarpa, at $29-32^{\circ} \mathrm{C}$. Values decreased from $10.2 \%$ to $4.7 \% \mathrm{TS}$. However, there was no significant difference $(p>0.05)$ in the TS values of sample stored for 3 and 4 weeks. The changes in total solid content were lower for samples stored at refrigeration temperature $\left(12^{\circ} \mathrm{C}\right)$. Values decreased from $11.2 \%$ TS in the fresh sample to $8.6 \%$ after 4 weeks of storage at $12^{\circ} \mathrm{C}$. TS values for weeks 3 and 4 were significantly lower than other values. For C.lepidota jam stored at 29$32^{\circ} \mathrm{C}$, TS values decreased significantly $(p<0.05)$ after the first week of storage. Further decrease $(p<0.05)$ was observed after the $3^{\text {rd }}$ week of storage. For C.lepidota jam stored at $12^{\circ} \mathrm{C}$, there was no statistical decrease in TS until the $3^{\text {rd }}$ week of storage. Further significant decrease $(p<0.05)$ was observed by the $4^{\text {th }}$ week of storage. The stability of total solids in C.lepidota jam stored at $12^{\circ} \mathrm{C}$ was similar to that of C.parchyarpa jam stored under refrigeration $\left(12^{\circ} \mathrm{C}\right)$ but the TS of C.lepidota jam stored at $29-32^{\circ} \mathrm{C}$ was more steady compared to that of C.parchyarpa stored at $29-32^{\circ} \mathrm{C}$. These differences could be attributable to varietal difference. C.parchycarpa juice stored at $29-32^{\circ} \mathrm{C}$ showed a sharp decrease in TS as storage period increased (9.7 to $4.1 \%)$. When stored at $12^{\circ} \mathrm{C}$, there were no significant changes in TS $(p>0.05)$ (9.7-9.5). A similar trend was observed for C.lepidota juice stored at $29-32^{\circ} \mathrm{Cand}$ C.lepidota juice stored at $12^{\circ} \mathrm{C}$. In this, it is likely that microorganisms in the products feed on the nutrients thereby reducing the total solids and the soluble solids to produce energy for their life activities; organic acids were also produced and are responsible for lowering the $\mathrm{p}^{\mathrm{H}}$.

The effect of storage temperature and time on the soluble solid (SS) of monkey kola products (juice and jam) (\%).

Changes in soluble solids (SS) of jam and juice from monkey kola are shown in Table 4. Soluble solids (SS) of C.parchycarpa jam stored at $29-32^{\circ} \mathrm{C}$ decreased significantly (from7.5 to $3.6 \%$ ) as the period of storage increased. The same trend was also observed in C.lepidota jam (except that decrease in SS of C.parchycarpa jam (3.9\%) was higher than decrease in 
Table 5. The effect of storage temperature and time on the titratable acidity of monkey kola products (jam and juice) (\%).

\begin{tabular}{|c|c|c|c|c|c|c|c|c|}
\hline Storage Time & $\begin{array}{l}\text { CPJm } \\
29-32^{\circ} \mathrm{C}\end{array}$ & $\begin{array}{c}\mathrm{CPJm} \\
12^{\circ} \mathrm{C} \\
\end{array}$ & $\begin{array}{l}\text { CLJm } \\
29-32^{\circ} \mathrm{C}\end{array}$ & $\begin{array}{l}\mathrm{CLJm} \\
12^{\circ} \mathrm{C}\end{array}$ & $\begin{array}{l}\text { CPJu } \\
29-32^{\circ} \mathrm{C}\end{array}$ & $\begin{array}{l}\text { CPJu } \\
12^{\circ} \mathrm{C} \\
\end{array}$ & $\begin{array}{l}\text { CLJu } \\
29-32^{\circ} \mathrm{C}\end{array}$ & $\begin{array}{l}\text { CLJu } \\
12^{\circ} \mathrm{C} \\
\end{array}$ \\
\hline Wk 0 & $0.1 \pm 0.7^{d}$ & $0.1 \pm 0.7^{b}$ & $0.1 \pm 0.1^{c}$ & $0.1 \pm 0.1^{b}$ & $0.2 \pm 0.0^{c}$ & $0.2 \pm 0.0^{c}$ & $0.2 \pm 0.0^{d}$ & $0.2 \pm 0.0^{c}$ \\
\hline Wk 1 & $0.1 \pm 0.7^{d}$ & $0.1 \pm 0.0^{b}$ & $0.1 \pm 0.7^{c}$ & $0.1 \pm 0.0^{b}$ & $0.2 \pm 0.1^{c}$ & $0.2 \pm 0.0^{c}$ & $0.2 \pm 0.1^{d}$ & $0.2 \pm 0.7^{c}$ \\
\hline Wk 2 & $0.3 \pm 0.1^{c}$ & $0.1 \pm 0.7^{b}$ & $0.2 \pm 0.7^{c}$ & $0.1 \pm 0.7^{b}$ & $0.3 \pm 0.1^{c}$ & $0.2 \pm 0.7^{c}$ & $0.4 \pm 0.2^{c}$ & $0.2 \pm 0.0^{c}$ \\
\hline Wk 3 & $0.3 \pm 0.2^{b}$ & $0.1 \pm 0.7^{b}$ & $0.3 \pm 0.2^{b}$ & $0.1 \pm 0.1^{b}$ & $0.6 \pm 0.7^{b}$ & $0.3 \pm 0.2^{b}$ & $0.7 \pm 0.1^{b}$ & $0.3 \pm 0.1^{b}$ \\
\hline Wk 4 & $0.5 \pm 0.7^{\mathrm{a}}$ & $0.2 \pm 0.1^{a}$ & $0.4 \pm 1.4^{a}$ & $0.3 \pm 0.7^{a}$ & $0.7 \pm 0.1^{a}$ & $0.4 \pm 0.2^{a}$ & $0.8 \pm 0.4^{a}$ & $0.4 \pm 0.1^{a}$ \\
\hline
\end{tabular}

Means with different superscripts along the same row are statistically different from each other $(P<0.05)$. CPJu C.parchycarpa

juice; CLJu - C.lepidota juice; CPUJm - C.parchycarpa jam;CLUJm - C.lepidota jam; Room Temperature -29 - 32=c; Refrigeration temperature $-12=\mathrm{C}$.

SS of C.lepidota jam (2.7\%). There was no significant decrease $(p>0.05)$ in SS of jam stored at $12^{\circ} \mathrm{C}$ until the $4^{\text {th }}$ week of storage. C.parchycarpa juice stored at 29$32^{\circ} \mathrm{C}$ showed a significant decrease in SS by the $3^{\text {rd }}$ week of storage. C.lepidota juice stored at the same temperature also showed a significant difference in SS $(P<0.05)$ after 2 weeks of storage. C.parcycarpa juice and C.lepidota juice at $12^{\circ} \mathrm{C}$ were more stable (showing a significant decrease in SS after 3 weeks of storage. The decrease SS was not in line with the finding of Rababah et al. (2011), who reported increase SS of strawberry jam and the reason for the differences may be because they added citric acid to their jam which must have inhibited microbial growth in the product. Decrease in soluble solids during storage in this study might be due to acid hydrolysis of poly saccharides especially gum and pectin (Luh and Woodroof, 1975).

The effect of storage temperature and time on the titratable acidity of monkey kola products (juice and jam) (\%).

Titratable acidity changes in jam and juice samples from monkey kola are shown in Table 5 . In all cases titratable acidity (TTA) increased as storage period increased. For C. parchycarpa jam stored at $29-32^{\circ} \mathrm{C}$ TTA increased from 0.11 to $0.55 \%$. For C.lepiota jam stored at the same temperature TTA increased from 0.13 to $0.44 \%$. This indicates that increase in TTA was lower for C.lepidota jam than for C.parchycarpa jam. Storage at $12^{\circ} \mathrm{C}$ (refrigeration temperature) led to more gradual increase in TTA, both for C.parchycarpa and for C.lepidota jams. Titratable acidity (\%) of juice from C.parchycarpa stored at $29-32^{\circ} \mathrm{C}$ increased from 0.21 to 0.75 (\%). TTA values for C.parchycarpa juice were significantly different $(p<0.05)$ after 2 and 3 weeks of storage at $29-32^{\circ} \mathrm{C}$. Changes in values for juice from C.lepidota followed the same pattern. At $12^{\circ} \mathrm{C}$, TTA values increased from 0.12 to $0.43(\%)$ for C.parchycarpa juice and from 0.23 to 0.39 (\%) for C.lepidota juice. In both cases, significant increases were observed by the $3^{\text {rd }}$ and $4^{\text {th }}$ weeks of storage. The increase in titratable acidity was more pronounced in the samples stored at room temperature $\left(29-32^{\circ} \mathrm{C}\right)$ than in those stored in the fridge $\left(12^{\circ} \mathrm{C}\right)$. The increase in acidity might be ascribed to rise in the concentration of weakly ionized acids and their salts during storage (Safdar et al., 2012). Increase in acidity might also be due to formation of acids by degradation of polysaccharides and oxidation of reducing sugars or by breaking of pectin substances and uronic acid (Iqbal et al., 2001). The increase in titratable acidity as observed under different storage temperature in this study was in line with similar work carried out by Ashaye and Adeleka (2009) on Roselle jam, on jam prepared from different mango varieties (Safdar, et al., 2012) and also on wood apple (Limonia acidissima) fruits (Vidhya and Narain, 2010).

\section{The effect of storage temperature and time on the total plate count of jam.}

The effect of storage temperature and time on the total plate count (TPC) of jam stored for 4 weeks is shown on Table 6. The total plate count of C.parchycarpa jam stored at room temperature increased from 2.0 to 42.4 $\times 10^{4}(\mathrm{Cf} \mu / \mathrm{g})$. The total plate count of $C$. lepidota stored at the same temperature also increased from 1.4 to $47 \mathrm{x}$ $10^{4}(\mathrm{Cf} \mu / \mathrm{g})$. The same pattern of growth was observed in the samples stored in the refrigerator but the multiplication was however lower than those of the 
Table 6. The effect of storage temperature and time on microbiological growth (TPC $\mathrm{cf}$ af/a) in jam

\begin{tabular}{|c|c|c|c|c|}
\hline & \multicolumn{3}{|c|}{ Total Plate count TPC $(\operatorname{cf} \mu / g)\left(10^{4}\right)$} & \multirow[b]{2}{*}{$\left(10^{\circ} \mathrm{C}\right)$} \\
\hline & $\mathrm{T}_{1}\left(29-32^{\circ} \mathrm{C}\right)$ & $\mathrm{T} 2\left(12^{\circ} \mathrm{C}\right)$ & $\mathrm{T} 1\left(29-32^{\circ} \mathrm{C}\right)$ & \\
\hline & & & CL. & \\
\hline Wk 0 & $2.0 \pm 0.1^{b}$ & $2.0 \pm 0.1^{b}$ & $1.4 \pm 0.2^{b}$ & $1.4 \pm 0.2^{b}$ \\
\hline Wk 1 & $3.5 \pm 0.3^{b}$ & $2.4 \pm 0.1^{b}$ & $5.5 \pm 0.1^{b}$ & $3.7 \pm 0.7^{b}$ \\
\hline Wk 2 & $6.1 \pm 0.1^{b}$ & $3.7 \pm 0.7^{b}$ & $6.7 \pm 0.7^{b}$ & $5.1 \pm 0.2^{b}$ \\
\hline Wk 3 & $35 \pm 0.1^{\mathrm{a}}$ & $25.5 \pm 0.7^{a}$ & $42 \pm 0.1^{a}$ & $18.5 \pm 0.2^{\circ}$ \\
\hline Wk 4 & $42.5 \pm 0.2^{\mathrm{a}}$ & $30 \pm 0.3^{\mathrm{a}}$ & $47 \pm 0.1^{\mathrm{a}}$ & $22.5 \pm 0.7^{2}$ \\
\hline
\end{tabular}

Means with different superscripts along the same row are statistically different from each other $(\mathrm{P}<0.05)$. CPJu - C.parchycarpa juice; CLJu - C.lepidota juice; CPUJm - C.parchycarpa jam;CLUJm - C.lepidota jam; Room Temperature -29 - 32=c; Refrigeration temperature $-12=\mathrm{C}$

Table 7. The effect of temperature and time on the microbial growth TPC $\left(\mathrm{cf}_{i t} / g\right)\left(10^{4}\right)$ in juice.

\begin{tabular}{|c|c|c|c|c|}
\hline & $\begin{array}{r}\text { CPJ } \\
\text { T1 }\left(29-32^{\circ} \mathrm{C}\right)\end{array}$ & $\mathrm{T} 2\left(12^{\circ} \mathrm{C}\right.$ & $\begin{array}{l}\text { CLJu } \\
\text { T1 }\left(29-32^{\circ} \mathrm{C}\right)\end{array}$ & $\mathrm{T} 2\left(12^{\circ} \mathrm{C}\right)$ \\
\hline Wk 0 & $2.5 \pm 0.7^{b}$ & $2.5 \pm 0.7^{b}$ & $3.8 \pm 0.2^{b}$ & $3.8 \pm 0.2^{\mathrm{b}}$ \\
\hline Wk 1 & $5.0 \pm 0.3^{b}$ & $3.6 \pm 0.2^{b}$ & $5.8 \pm 0.1^{b}$ & $4.3 \pm 0.1^{\mathrm{b}}$ \\
\hline Wk 2 & $6.4 \pm 0.1^{b}$ & $3.9 \pm 0.2^{b}$ & $7.7 \pm 0.3^{b}$ & $5.1 \pm 0.3^{b}$ \\
\hline Wk 3 & $46 \pm 1.4^{a}$ & $29 \pm 1.4^{a}$ & $51 \pm 0.7^{a}$ & $42 \pm 0.7^{a}$ \\
\hline Wk 4 & $51.5 \pm 2.1^{\mathrm{a}}$ & $34 \pm 2.1^{a}$ & $56 \pm 2.1^{a}$ & $49 \pm 2.1^{\mathrm{a}}$ \\
\hline
\end{tabular}

Means with different superscripts along the same row are statistically different from each other $(P<0.05)$. CPJu - C.parchycarpa juice; CLJu - C.lepidota juice; CPUJm - C.parchycarpa jam;CLUJm - C.lepidota jam; Room Temperature -29 - $32{ }^{\circ} \mathrm{C} ;$ Refrigeration temperature $-12=\mathrm{C}$.

samples stored at room temperature. This implies that low temperature slows down microbial multiplication. In all the samples the TPC for the first two weeks were not significantly $(p<0.05)$ different from each other but differed significantly from the TPC of weeks 4 to 5.This implies that microorganisms increase with increase in storage time. The high TPC seen in C. lepidota jam stored at room temperature is attributable to its total sugar content; the sugar content will increase (not decrease) microbial growth because the sugar is a nutrient which microbes will use for their metabolic processes (Hoover, 1997). C. lepidota jam started with a low plate count compared to C.parchycarpa jam. The total plate count for C.parchycarpa jam stored in the refrigerator varied between 2.0 to $30 \mathrm{Cf} \mu / \mathrm{g}$, while that C.lepidoda jam varied between 1.4 to $22.5 \mathrm{Cf} \mu / \mathrm{g}$. This result implies that C.lepidoda jam stores better than that of C.parchycarpa at cold temperature. The result however showed that the jams can still be consumed even after 4 weeks of storage because the TPC was still below $10^{6} \mathrm{cffk} / \mathrm{g}$ (ICMSR, 1994).
The effect of storage temperature and time on the total plate count $(c f z / g)$ in juice.

The effect of storage temperature and time on the total plate count (TPC) $(\mathrm{c} f \mathrm{k} / \mathrm{g})$ of the juice stored for 4 weeks is shown on Table 7. The TPC increase as storage period increased in juice from C.parchycarpa, at $29-32^{\circ} \mathrm{C}$. The total count increased from 2.5 to $51.5(\mathrm{c} f(h / \mathrm{g})$. There was no significant $(p<0.05)$ difference in the TPC values of the sample stored for 1 and 2 weeks. For samples stored in the refrigerator, insignificant growth was also recorded for the first 2 weeks. Rapid growth was observed by the $3^{\text {rd }}$ and $4^{\text {th }}$ weeks. The rapid decline in microbial count indicates that the nutrient was used up and microbes were no longer growing. Rather they were in stationary or death phase. Growth of microorganism has five staged; lag phase, log phase, exponential growth phase, stationary phase and death phase. Microbial growth, which is an indication of increased microbial count, only takes place during the log phase and the exponential growth phase. The TPC of C.lepidota juice stored at 
room temperature for 4 weeks ranged between 3.8 to 56 $\left(c f_{k} / \mathrm{g}\right)$ while the one stored in the refrigerator ranged between 3.8 to 49 (c $f / k / g)$ indicating that cold temperature inhibits microbial multiplication in food products. Microbial contaminates were found in all the samples analysed; bacteria found on fruit surfaces comprise the most frequent spoilers of fruit juice because they exist on the surface of plant and fruits growing at the expense of secreted plant materials (Frazier and Westhoff, 1998). However, data regarding total plate count of the samples within the study period were well within permissible limits (ICMSR, 1994). The low count could be attributed to pasteurization and proper handling. The major contaminants isolated were Baccillus subtilis, Clostridium butyrium, and Sacharomyces spp. The presence of these organisms in the products could be due to the low pH of the products (Tournas et al., 2005). The presence of these organisms though in low amount need to be controlled to prevent spoilage and food borne illness (Mudgil et al., 2004; Oranusi et al., 2004; 2007).

\section{CONCLUSION}

The results of this study showed that the shelf-life of the products (jam and juice) produced from monkey kola can be extended by storing them in the refrigerator. Further investigation on how to keep the products longer is however recommended.

\section{ACKNOWLEDGEMENT}

We wish to express our gratitude and appreciation to Mr. Paul Nwosu of National Root crop Research Institute Umudike, Abia State for carrying out the chemical analysis and Dr. S. Abasiekong for carrying out the statistical analysis.

\section{REFERENCES}

Adepoju OT, Adegun MO, Lawal IM, Olaide EA(2010). Nutrient and anti-nutrient composition of jam preparation from Hibiscs sabdariffa calyx extract. Niger. J. Nutr. 31: 8-11.

Association of Official Analytical Chemist (A.O.A.C.). (2006). Official Methods of Analysis. Association of Official Analytical Chemistry. Washington D.C.

Ashaye OA, Taiwo OO, Adegoke GO(2006). Effect of local Preservatives (Aframomum danielli) on the chemical and sensory properties of stored warakanshi. Afri. J. Agric. Res. 1:10-16.

CTA (2012). Going to waste-missed opportunity in the battle to improve food security. CTA policy Brief,7. www.cta.int/joomlatoolsfiles/documan-files/policy papers/7 Going to waste missed. Retrieved 02/04/2015.
Fasoyiro SB, Ashayi OA, Adeola A, Samuel FO(2005).Chemical and storability of fruit flavoured (Hibiscus sabdariffa). Drinks .World J. Agric. Sci.1:165-168.

Frazier WC, Westhoff DC(1998). Food microbiology. 4th ed. Mc Graw Hill: New Delhi.

Hoover DG(1997). Manually processed fruits and vegetables, reducing microbial loads by non-thermal physical treatment. Fd. Tech. J. 57:66-69.

Hussain I, A Zeb, I Shakir, Shah AS(2008). Combined effect of potassium sorbate and sodium benzoate on individual and blended juices grown in Azad Jammu and Kashmir. Pak. J. Nutr. 7: 181185.

Iqbal SA,Yasmin S, Wadud A, Shah WH(2001). Production, storage packing and quality evaluation of guava nectar. Pak. J. Fd. Sci. 11:33-36.

Ihekoronye IA, Ngoddy $\mathrm{PO}(1985)$. Integrated food science and technology for the tropics. Macmillian Publishers Ltd: Ibadan.

Kvikliene N, Kviklys D, Viškelis $\mathrm{P}(2006)$. Change in fruit quality during ripening and storage in the apple cultivar (Auksis). J. Fruit Ornam. Plant Res. 14:195-202.

Luh BS, Woodroof JG(1975).Commercial vegetable processing. The AVI Publishing Company: Westport, Connecticut, USA

International Commission on Microbiology Specifications for Food (ICMSF). (1978). International Committee on microbiological specifications of microbiological specifications of microorganisms. $2^{\text {nd }}$ ed: Toronto Press.

Mudgil S, Argawal D, Ganguh A(2004). Microbiological analysis of street vended fresh squeezed carrot and kinnow mandarin juice in Patiala city India, Int'l. J. Food. Safety. 3:1-3.

Ogbu JU, Essien BA, Kadurumba $\mathrm{CH}(2007)$. Nutritional value of wild Cola spp. (Monkey kola) fruits of Southern Nigeria. Nig. J. of Hort. Sci. 12: 113-117.

Ene-Obong HN, Okudu HO, Asumugha VU(2014). Nutrient and phytochemical composition of two varieties of monkey kola (Cola parchycarpa, Cola lepidota). An underutilized fruit. Accepted for publication in J. Food Chem. (2014).

Okudu HO, Ene-Obong HN(2015). The chemical and sensory properties of jam developed from two

varieties of monkey kola Ccola parchycarpa, Cola lepidota). Am. J. Food Nutr. 5(1): 16-22.

Okudu HO, Ene-Obong HN, Asumugha VU(2015). The chemical and sensory properties of juice developed from two varieties of monkey kola (Cola parchycarpa, Cola lepidota). Afr. J. Food Sci. Technol. 6(5): 149-155,

Oranusi S, Onyeike E, Galadima M, Umoh VJ(2004). Hazard analysis critical control points of foods prepared by families in Zaria, Nigeria. Nig. J. Microbiol. 18:346-362.

Oranusi S, Galadima M, Umoh VJ, Nwanze PI(2007). Food safety evaluation in boarding schools in Zaria, Nigeria, using the HACCP system. Scientific Research and Essay. 2:426-433.

Rababah T M, Al-Mahasneh MA, Kilani I, Yang W, Alhamad MN, Ereifej $\mathrm{K}(2011)$. Effect of jam processing and storage on total phenolics, antioxidant activity, and anthocyanins of different fruits. J. Sci. Food. Agric. 91: 1096-1102.

Safdar MN, Mumtaz A, Hameed T, Siddiqui N, Khalil S, Amjad $\mathrm{M}(2012)$. Storage studies of jam prepared from different mango varieties. Pak. J. Nutr. 11:555-561.

Saka J, Rapp IA, kinnifesi F, Ndolo V, Mhango J(2007). Physicochemical and organoleptic characteristics of Uapaca kikiana, cocculoide, Adansonia digitata and Mangiferia indica fruit products. Int'l. J. Fd. Sci. Techno.42:836-841.

Singh B, Gupta V, Bansal P, Singh R, Kumer, D(2010). Pharmacological potential of plant used as asphrodisiacs. Int'l. J. Pharm. Sci. Rev. Res. Pp104-107.

Tahir MI, Khalique A, Pasha TN, Bhatti JA(2002). Comparative evaluation of maize bran, wheat bran and rice bran on milk 
Okudu and Ene-Obong 203

production of Holstein Friesian cattle. Int. J. Agric. Biol. 4 (4): 559560

"The wander of carrot juice" Accessed March $10^{\text {th }} 2013$ from www. Carrotmuseum.com

Tournas VH(2005). Moulds and yeasts in fresh and minimally processed vegetables and sprouts. Int'l J. Fd. Micro. Pp 99:71-77.

Umeh AS, Nwadialu MA(2010). Production and proximate analysis of jam (food spread) prepared from Cola pachycarpa. JHER. 13: 152158.
Vidhya R, Narain A(2010). Development of preserved products (jam and fruit bar) from under exploited wood apple "Limonia acidissima" fruits. African J. Fd. Sci.Tech. Pp 051-057.

Wicklund T, Rosenfeld HJ, Martinsen BK, Sundfor MW, Lea P, Bruun $\mathrm{T}$, Blomhoff R, Haffner K( 2005). Antioxidant activity capacity and colour of strawberry jam as influenced by cultivar and storage conditions. J. Food. Sci. Technol. 38:387-391. 